\title{
A clinical trial for patients with acute myeloid leukemia or myelodysplastic syndromes not eligible for standard clinical trials
}

G Montalban-Bravo, X Huang, K Naqvi, E Jabbour, G Borthakur, CD DiNardo, N Pemmaraju, J Cortes, S Verstovsek, T Kadia, N Daver, W Wierda, Y Alvarado, M Konopleva, F Ravandi, Z Estrov, N Jain, A Alfonso, M Brandt, T Sneed, HC Chen, H Yang, C Bueso-Ramos, S Pierce, E Estey, Z Bohannan, HM Kantarjian and G Garcia-Manero

Leukemia (2017) 31, 1659; doi:10.1038/leu.2017.85; published online 24 March 2017

Correction to: Leukemia (2017) 31, 318-324; doi:10.1038/leu.2016.303; published online 18 November 2016

Following the publication of this article, the authors noted that Dr Naqvi's name should have been included. The complete and correct author names appear above. Dr Naqvi's affiliation is Department of Leukemia, University of Texas MD Anderson Cancer Center, Houston, TX, USA.

\section{Epistasis between TIFAB and miR-146a: neighboring genes in $\operatorname{del}(5 q)$ myelodysplastic syndrome}

ME Varney, K Choi, L Bolanos, S Christie, J Fang, HL Grimes, JP Maciejewski, J-I Inoue and DT Starczynowski

Leukemia (2017) 31, 1659; doi:10.1038/leu.2017.95; published online 7 April 2017

Correction to: Leukemia (2017) 31, 491-495; doi:10.1038/leu.2016.

276; published online 11 November 2016
Following the publication of this article, the authors noted that Dr Grimes' name was incorrect. The complete and correct author names appear above.

\section{Cobll1 is linked to drug resistance and blastic transformation in chronic myeloid leukemia}

SH Han, S-H Kim, H-J Kim, Y Lee, S-Y Choi, G Park, D-H Kim, A Lee, J Kim, J-M Choi, Y Kim, K Myung, H Kim and D-W Kim

Leukemia (2017) 31, 1659; doi:10.1038/leu.2017.107; published online 11 April 2017

Correction to: Leukemia (2017) 31, 1532-1539; doi:10.1038/leu.2017.72; published online 14 March 2017
Following the publication of this article, the authors noted that Dr S-H Kim should have been noted as an equally contributing co-first author. 